\section{Modelling Innovation Activities Using Discrete Choice Panel Data Models}

\author{
Ester Martínez-Ros and José M. Labeaga*
}

\subsection{INTRODUCTION}

The main purpose of this chapter is to analyze the determinants of innovation activity using Spanish data at firm level corresponding to the manufacturing sector. We focus on the relationship between the R\&D effort undertaken by firms, and the innovation decision claimed by them. We are really estimating a research production function (see, for example, Crépon and Duguet, 1997), where we include other controls as firm characteristics and market conditions in addition to the typical inputs.

Previous studies (Bound et al., 1984; Hall et al., 1986; or GarcíaMontalvo, 1993) have examined the research function using lagged $R \& D$ expenditures as a measure of inputs, and patents as the output. This chapter departs from those studies in several ways. First, we explain the innovation decision rather than the number of patents. Moreover, we exploit the information available in the survey about the possibility of distinguishing product innovation from process innovation. An advantage of this indicator, as Griliches (1990) argues, is that it retrieves more closely the innovation activity because not all-technical research transforms into patents. Another advantage is the possibility of assessing the kinds of innovation carried out, which is not possible when using patents.

Second, we use the knowledge capital stock instead of lagged R\&D expenditures as input within the research production function. It assumes that the firm's effort takes R\&D as a specific input, in order to explain value-added differences among firms. The use of these variables has precedents in Hall and Mairesse (1993), and Crépon and Duguet (1997), using French data. Following this idea, we also introduce the industrial knowledge capital removing the own-firm R\&D expenditures, in order to capture opportunity externalities in the product market.

Third, we consider additional determinants of innovation activity in the research production function and we separate them into two categories: firm characteristics and market conditions. In the former, we include firm size, capital intensity or the degree of vertical integration. In the latter, we assume that market concentration, growth of demand or the product elasticity could modify the firm innovation strategy.

The econometric treatment takes into account both that the dependent variables are binary, and that we have panel data at hand. We use several alternatives for estimating static and dynamic versions of the models. First, we estimate a pooled logit in levels under the assumption of absence of unobserved heterogeneity (see Amemiya, 1986). Second, we assume a specific distribution for the unobserved heterogeneity and estimate random effects logit models. Third, we use a two-step method following Chamberlain (1984), where in the first step we specify linearly the conditional mean of the effects, and in the second we devise the parameters of interest using a within-groups procedure.

There are important differences among the alternatives. When moving from one method to one another, we try to emphasize the importance of controlling for unobserved heterogeneity, but also the need to allow for specific feedback effects among some of the determinants of the innovation decision and the innovation itself (as in Blundell et al., 1995, for example). Moreover, we relax the absence of correlation among firm heterogeneous effects and regressors, which is a crucial matter in the models, including the lagged dependent variable, as has been revealed in previous empirical applications (see, for example Hausman et al., 1984). Finally, we take account of the possible simultaneity between the decisions to innovate in process and product.

The empirical evidence indicates that in the decisions to carry out innovations, there are different determinants (or effects) in the two equations. Moreover, we find that the lagged own dependent variable is important, while, after controlling for this dynamic effect, the significance of the alternative innovation indicator vanishes. Large firms in a highly concentrated market only find it profitable to carry out product innovations. On the other hand, we observe that the effect of technological opportunity disappears when we control for both experience and firm effects. Spanish manufacturing firms fulfil the Schumpeterian hypothesis in terms of the degree of market competition, but it is not possible to make conclusive comments as regards firm size. Size seems to be important for carrying out product innovation, but this is not the case for process innovation decisions.

The chapter contains four sections. Section 7.2 describes briefly the data supporting the specification used in the empirical section. We set up the theoretical framework, specify the model and explain the econometric 
techniques in Section 7.3. The empirical results are reported in Section 7.4, and Section 7.5 concludes.

\subsection{AN INFORMAL LOOK TO THE DATA}

It is very difficult to find satisfactory measures of new knowledge and the value of an invention to be used in empirical analyses (Griliches, 1990). In fact, the measure of technical change or innovations is approximated by a variety of variables, distinguishing between inputs and outputs of an innovation. One feature of this chapter is the use of an alternative output of innovation: the product and process innovation indicators. Our data set allows us the use of this kind of information. It corresponds to the Encuesta Sobre Estrategias Empresariales (ESEE) which was conducted over the period 1990-3 and surveyed over 2000 firms. This is an unbalanced panel, since some firms did not continue to provide information, for several reasons (mergers, changes to non-industrial activity, or ceasing production). New companies were included in the survey each year in an attempt to maintain representativeness. It therefore constitutes a mixed data set, where small companies (with fewer than 200 employees) are selected randomly using strata corresponding to four size intervals and twenty-one groups of two-digit industry codes of the CNAE, ${ }^{1}$ while for large firms (more than 200 employees) the sample is exhaustive. After selecting the sample for inconsistencies in the variables, we have a balanced panel with 923 firms for each year. ${ }^{2}$

In order to offer a brief description of this survey, we group the sample using production activity and firm size. Production activity refers to the industries whose firms belong to, and the classification corresponds to, the NACE-CLIO. In this classification, we have available eighteen manufacturing sectors, but these have been aggregated into five for our analysis. Table A7.1 in the Appendix (see page 168) presents the definition of the industry variables and their correspondence with the original classification of sectors. The size aggregation is constructed using the number of employees at 31 December. It implies that we have to weight temporary workers using the period during which they have been hired by the firm. The ESEE uses specific size intervals: fewer than 20 workers, between 21 and 50, between 51 and 100, between 101 and 200, between 201 and 500, and more than 500. This aggregation is suitable for the typical Spanish structure (Segura, 1993). The industry classifications as well as the size intervals are constructed to maintain the representativeness of the sample.

Table A7.2 in the Appendix (see page 168) presents some descriptive statistics for three sample classifications as well as definitions of the variables.
The first column corresponds to all firms in the sample, while the remaining two columns correspond to samples for product and process innovating firms, respectively. Although there are differences among the three subsamples, the main ones appear between the whole sample and the two subsamples of innovating firms. The share of exporters with foreign capital ownership is larger in the subsamples of innovators than in the whole sample. On the other hand, firms with high levels of physical capital or more vertical integrated are not necessarily the most innovative. Comparing the frequencies by sector, there are more firms innovating in the electrical materials and machinery, motors and vehicles than in the whole sample, and fewer firms in the food and beverages, and leather, wooden and paper than in the whole sample. Finally, these simple measures do not show that large firms are significantly more innovative than small ones.

Two of the main issues addressed when analyzing innovation equations (either the number of patents or the innovation counts) are the dynamic structure of the input variables which enter the equation of interest and the experience effects; that is, the dynamics of the lagged dependent variables. In this chapter, we are only interested in estimating the decision to innovate, ${ }^{3}$ but it should also be crucial to account for the experience effect, in the sense that the probability of innovating today could be affected not only by past realizations but also by the probability of innovating in the past. On the other hand, there could be some lag between the effort that the firm makes and the possible success (see Hall et al., 1986). Our sample only contains four periods, and this small time series dimension could cause problems of lag truncation or lack of identification of the dynamic structure of the model. In the rest of this section, we try to justify the empirical specification used below concerning a way of solving these problems.

Table 7.1 shows the unconditional probabilities of innovating in product and process as well as several conditional frequencies; 25.5 per cent of the sample made product innovations over the whole period, and 31.1 per cent conducted process innovations. Looking at the frequencies over the four years, we observe the expected path. Frequencies for product innovations are 19.5, 27.52, 28.49 and 26.54 in 1990, 1991, 1992 and 1993, respectively, while for process innovations the respective frequencies are 19.07, $37.38,33.91$ and 34.13 . The innovation frequencies are affected by the economic crisis of 1992. However, this crisis affected process innovations before product innovations. We can observe a big jump in the frequency when moving from unconditional probabilities to conditional on the most recent past. Firms innovating in product in the previous year, increase the probability of innovating in product today to more than 150 per cent. Firms innovating in process in the previous year increase the probability of 
Table 7.1 Frequencies of innovation

\begin{tabular}{|c|c|c|}
\hline & $\begin{array}{l}\text { Product } \\
\text { innovation } \\
\text { in } t\end{array}$ & $\begin{array}{l}\text { Process } \\
\text { innovation } \\
\text { in } t\end{array}$ \\
\hline Unconditional probability & 0.255 & 0.311 \\
\hline \multicolumn{3}{|l|}{ Conditional probabilities } \\
\hline Product innovation in $t$ & - & 0.628 \\
\hline Process innovation in $t$ & 0.515 & - \\
\hline Product innovation in $t-1$ & 0.637 & 0.529 \\
\hline Process innovation in $t-1$ & 0.436 & 0.655 \\
\hline $\begin{array}{l}\text { Product innovation in } t-1 \\
\text { and in } t-2\end{array}$ & 0.734 & 0.575 \\
\hline $\begin{array}{l}\text { Process innovation in } t-1 \\
\text { and in } t-2\end{array}$ & 0.476 & 0.736 \\
\hline $\begin{array}{l}\text { Product innovation in } t-1 \text {, } \\
\text { in } t-2 \text { and in } t-3\end{array}$ & 0.790 & 0.629 \\
\hline $\begin{array}{l}\text { Process innovation in } t-1 \text {, } \\
\text { in } t-2 \text { and in } t-3\end{array}$ & 0.566 & 0.829 \\
\hline $\begin{array}{l}\text { Product and Process } \\
\text { innovations in } t-1\end{array}$ & 0.679 & 0.695 \\
\hline $\begin{array}{l}\text { Product and Process } \\
\text { innovations in } t-1 \text { and } t-2\end{array}$ & 0.744 & 0.763 \\
\hline $\begin{array}{l}\text { Product and Process } \\
\text { innovations in } t-1, t-2 \text { and } t-3\end{array}$ & 0.784 & 0.811 \\
\hline
\end{tabular}

innovating in process today by 110 per cent. This experience effect is smaller after two or more periods engaging innovations. When conditioning on two previous years, the probabilities increase by 15 and 12 per cent respectively, while the respective increments are 7.6 and 12.5 per cent when conditioning on innovating in three previous periods.

Finally, we also report in Table 7.1 the conditional frequencies when the condition subset includes not only experience of own innovation but also of the alternative. Once we condition on the own past decision, the frequencies do not change a lot when augmenting the conditioning set by the alternative innovation event. For instance, the probability of innovating in product (process) is 6.6 (6.1) per cent larger for a firm innovating simultaneously in product and process in $t-1$ than for a firm only innovating in product (process). These changes in the frequencies reduce as we extend the conditioning set. While all these empirical findings must be confirmed in the regression analysis, they seem to allow us the use of a parsimonious specification in the innovation decision equations. Some models, as proposed by Heckman (1981), it seems, do not need estimating. We do not estimate a model in which the experience effect is multiplicative (that is, a product of the innovation indicator for all lags of the dependent variable), for instance. Moreover, once controlling for own effect, the alternative measure of innovation does not seem to produce an improvement in the innovation frequencies.

\subsection{THEORETICAL FRAMEWORK, EMPIRICAL SPECIFICATION AND ECONOMETRIC METHODS}

\subsubsection{A Model for Innovation Decisions}

We measure the different determinants of technological innovation assuming the existence of a dynamic process in both decisions. This chapter considers the technological research as a heterogeneous activity, being important to distinguish between research addressed towards process innovation, and research addressed towards product innovation. Since process innovation is more related to firm costs, and product innovation focuses on product differentiation, we expect that the determinants of innovation types and the effects of other variables will be different (Lunn, 1986; Martínez-Ros, 1998).

We estimate the research production as a function of past research $(S)$ and other control variables $(X)$ which reinforce the achievement of new inventions:

$$
E\left(I_{i t}\right)=f_{i}\left(S_{i t-1}, X_{i t-1}\right)
$$

Past research is measured as a knowledge stock variable rather than by using the traditional proxy $R \& D$ expenditures. So, we substitute expenditure on R\&D by knowledge research, $G_{i t}$, constructed as actual R\&D expenditures produced within the firm plus the past-period knowledge which depreciates at a rate $(\delta)$ as a result of imitation:

$$
G_{i t}=S_{i t}+(1-\delta) G_{i t-1}
$$

With this formulation, we assume that research contributes towards the innovation stock by generating a constant stream of incremental innovations. ${ }^{4}$ In this equation, the relative productivity of research is a function of the technological opportunity in the industry, $\tau$, so the marginal productivity will be $\partial f_{i t} / \partial S_{i t}=\tau_{i t}$. Technological opportunity or product market externalities reflect the influences of technological push in the industry 
which occurs when exogenous changes in scientific and engineering knowledge reduce the costs of new processes and so increase the benefit of the firm (Lunn, 1986).

Related to other conditionings, $X$ contains variables as firm characteristics or market environment that could affect the firm innovation decision. Specifically, we focus on testing the effect of firm size and market competition. On the one hand, following the Schumpeter tradition, we expect a positive sign in the innovation probabilities for larger firms, since they have more complementary financial, physical and commercial resources that provide for the development of more innovation activity. However, large firms may also be subject to controls that are more bureaucratic and this may have a negative effect on their capacity to translate capital stock into innovations. Moreover, if size is associated positively with market power, the incremental benefits of innovation may be lower for larger firms than for smaller ones. On the other hand, we could also think that the relationship between innovation activity and firm size is not monotonic. In the case of observing a size threshold, we must allow for quadratic profiles, for example (see Pavitt et al., 1987, or Kleinknecht, 1989).

Market concentration would also increase innovation probabilities, both in product and process, according to the Schumpeter hypothesis, because firms that act as a monopoly have more incentives to maintain innovations as a barrier to entry. However, we can find a reverse effect, where firms in a more competitive market obtain larger profits when they develop innovation activity (Arrow, 1962). So the empirical evidence on this issue is not conclusive (see Levin and Reiss, 1989).

\subsubsection{The Empirical Specification}

Since we have available in our database the kinds of innovation in which firms engage (product or process), we can separate the innovation output in these two types and estimate the research production function for the two innovation decisions. Consequently, we are going to estimate the following two specifications for Equation (1):

$$
\begin{aligned}
& I P R O D_{i t}^{*}=g\left(G_{i t-1}, X F I R M_{i t-1}, \tau_{i t-1}, X M A R K E T_{i t-1}, \varepsilon_{2 i t}\right) \\
& \operatorname{IPROC}_{i t}^{*}=g\left(G_{i t-1}, X F I R M_{i t-1}, \tau_{i t-1}, X^{\prime} \text { MARKET }_{i t-1}, \varepsilon_{l i t}\right)
\end{aligned}
$$

where IPROD is the indicator of product innovation of firm $i$ in period $t$, so that $I P R O D_{i t}=1$ if $I P R O D_{i t}^{*}>0$, and IPROD ${ }_{i t}=0$ otherwise, and $I P R O C$ is the indicator of process innovation with $I P R O C_{i t}=1$ if
$I P R O D_{i t}^{*}>0$, and IPROC $C_{i t}=0$ otherwise. We denote by $\varepsilon_{1 i t}$ and $\varepsilon_{2 i t}$ the error terms, which are decomposed into mixed errors and heterogeneous effects in some of the models estimated below. ${ }^{5}$

Equations (3) and (4) explain the innovation activities through their main determinants. We use as dependent variables the two dummies (IPROD and $I P R O C$ ) because the ESEE provides this information directly from the firm's questionnaire. The effect of experience is introduced using the lagged latent dependent variables $I P R O D_{i t-1}^{*}$ and IPROC $C_{i t-1}^{*}$ or the lagged observed dependent ones, depending on the specification. These two cases differ in assuming whether only past innovation is important, or if the probability to innovate in the past could affect the current probability.

Notice that innovation activity is conditioned on the technological capital stock of the firm $\left(G_{t-1}\right)$ which captures the previous R\&D effort carried out by a firm affected by a depreciation rate. We assume a depreciation rate of 30 per cent as do numerous studies. It is constructed as in Equation (2) and normalized by firm sales. It represents the depreciated sum of past innovation search relative to sales. This implies that Equations (3) and (4) can be interpreted as pseudo-production functions of innovations, where XFIRM and XMARKET are explanatory variables of the innovation activity of the firm, for a given capital stock. Some variables included in XFIRM and XMARKET may also affect the capital stock $G_{t-1}$; that is, the stock should be considered endogenous. To account for this, $G_{t-1}$ will be instrumented by its prediction GINST $_{t-1}$, which has been obtained by regressing $G_{t}$ on industry and time dummies, firm characteristics, market characteristics and the past knowledge stock, under the assumption that the error term in this auxiliary regression is not autocorrelated.

Among XFIRM we include size, production technology, vertical integration, export activity and foreign ownership. Firm size is measured by the logarithm of the number of employees $(\ln E M P)$. As explained above, a positive sign would be in line with the Schumpeter propositions. But as there may also be negative effects of size on innovation activity after a threshold has been passed, we account for this possibility by using a quadratic relationship (ln EMP2).

The production technology is proxied by the ratio of fixed assets to sales of the firm $(K S A)$. It represents the replacement value of the firm's machinery capital stock and is constructed following the traditional literature about the measure of capital stock (Blundell et al., 1992). The tangible capital captures the positive effect of internal financing on research activity via reduction in costs. We also consider a dummy variable that captures the foreign ownership (CAPEXT). We like to test whether there is a discipline effect of firms with foreign capital on national ownership firms (see Baldwin et al., 1999). 
panel data on firms where $T$ is finite, there are only a limited number of observations of $y_{i t}$ that contain information about $\eta_{i}$. Any estimation of $\eta_{i}$ is meaningless in this case because of the problem of incidental parameters. ${ }^{6}$

Since the number of firms $N$ tends to infinity, we are interested in inferences for the manufacturing sector, and the fixed effects interpretation loses some sense. Moreover, the impossibility of including non-strictly exogenous variables (predetermined, for instance) makes this model very restrictive. If the effects are treated as random, $\varepsilon_{i t}=\eta_{i}+u_{i t}$, this is known as an error components model. We do not consider a time component in the error because the time-span of the sample is very small, and time dummies will control for these effects. We can consider two possibilities: (i) $\eta_{i}$ and $x$ are not correlated; and (ii) $\eta_{i}$ are not independent of $x$ (or of some of the regressors). Assuming that the explanatory variables and the effects are orthogonal, one can write the joint likelihood of $\left(y_{i t}, \ldots, y_{N t}\right)$ without taking into account heteroscedasticity. Notice that even if $u_{i t}$ are independently distributed over $i$ and $t, E\left(\varepsilon_{i t}, \varepsilon_{i s}\right)=\sigma_{\eta}^{2} \neq 0 ; \eta_{i}$ is a random sample from a univariate distribution $G$, indexed by a finite number of parameters $\delta$. Then, the log-likelihood function becomes:

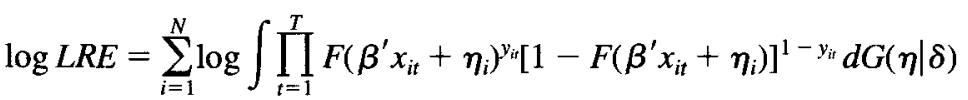

But the absence of correlation among $\eta_{i}$ and $x$ has limited interest in our exercise. Managerial ability or corporate culture could induce more innovation activity that subsequently needs more resources, for example. In that case, the unobserved effect managerial ability would be correlated with some of the regressors. Moreover, the panel nature of the data does not provide advantages over a pure cross-section, except on efficiency grounds. If the effects are not orthogonal to the explanatory variables, $M L$ will yield biased estimators for $\beta$. To allow for dependence between $\eta_{i}$ and $x$, we can specify a distribution for $\eta$ conditional on $x$. A possibility suggested by Chamberlain (1984) is to assume that $\eta_{i}=\Sigma_{t=1}^{T} \alpha_{t} x_{i t}+\nu_{i}$. Now we are assuming that the regression function $E\left(\eta_{i} / x_{i t}\right)$ is in fact linear, and that $v_{i}$ has a specific distribution. Given these assumptions, the loglikelihood function under our random-effects specification is:

$$
\log L L E=\sum_{i=1}^{N} \sum_{t=1}^{T}\left[y_{i t} \log F_{i t}+\left(1-y_{i t}\right) \log \left(1-F_{i t}\right)\right]
$$

where now $F_{i t}=F\left(\beta^{\prime} x_{i t}+\sum_{s=1}^{T} \alpha_{s} x_{i s}\right)$ and $F$ could again be the cumulative distribution function of the standard normal (probit model) or the logistic distribution (logit model). Chamberlain (1984) shows that we can estimate each of the $T$ (reduced form) models by maximum likelihood (that is, $T$ probits or logits) and then we can find the parameters of interest $\beta$ by minimum distance in a second step. We derive the parameters of interest using a within-groups procedure at the second stage instead of minimum distance for simplicity (see Bover and Arellano, 1997), although at the cost of obtaining parameter estimates that are inefficient relative to those obtained by minimum-distance. ${ }^{7}$ Our two-step procedure runs as follows. First, we estimate $T$ discrete choice models (one for each cross-section) and form predictions for each $i$ and $t$ using the reduced-form parameters. At the second stage we use the predicted latent indicators, which are now observed variables, to estimate the structural form parameters. Since the model incorporates firm heterogeneity, we transform the variables to deviations from individual means (within-groups) in order to rule out these effects at the level of the structural form of the model.

\subsection{EMPIRICAL RESULTS AND DISCUSSION}

Tables 7.2 and 7.3 present the estimates of the models reported in the previous section. We assume that the distribution of the mixed errors is logistic. Results using probit models are very similar because the logistic is very close to the normal distribution (see Cox, 1970). In econometric terms, there are two issues in which we are interested. The first concerns individual heterogeneity while the second considers the experience effect.

In order to see the impact on the estimators of controlling for firm effects, we focus first on the static specifications (Table 7.2). The importance of unobserved effects can be checked by comparing the results in columns one and three (product innovation), or columns two and four (process innovation). The impact of all factors affecting innovation probabilities is reduced when moving from homogeneous to heterogeneous models. If, as expected, time invariant unobserved variables (managerial ability, corporate culture or specific know-how) affect innovation frequencies positively, the magnitude of the effects of the observables are biased upwards when we do not consider them. The homogeneity tests (LR) compare the likelihood values of specifications with and without heterogeneity, and clearly reject the null at standard significance levels. So, firm effects are important determinants of the innovation frequencies, and their absence could lead to wrong inferences. 
Table 7.2 Static models

\begin{tabular}{|c|c|c|c|c|c|c|}
\hline & \multicolumn{2}{|c|}{ Pooled levels } & \multicolumn{2}{|c|}{ Random effects } & \multicolumn{2}{|c|}{ Linear effects } \\
\hline & IPROD & IPROC & $I P R O D$ & IPROC & IPROD & IPROC \\
\hline Intercept & $\begin{array}{c}-2.713^{*} \\
(1.27)\end{array}$ & $\begin{array}{c}-3.767^{*} \\
(1.18)\end{array}$ & $\begin{array}{c}-2.705^{*} \\
(1.05)\end{array}$ & $\begin{array}{c}-4.167^{*} \\
(1.02)\end{array}$ & - & - \\
\hline GINST/IO & $\begin{array}{l}0.810^{*} \\
(0.15)\end{array}$ & $\begin{array}{l}0.638^{*} \\
(0.15)\end{array}$ & $\begin{array}{l}0.413^{*} \\
(0.15)\end{array}$ & $\begin{array}{l}0.604^{*} \\
(0.16)\end{array}$ & $\begin{array}{c}-0.089 \\
(0.08)\end{array}$ & $\begin{array}{c}0.026 \\
(0.06)\end{array}$ \\
\hline$S P I L L$ & $\begin{array}{c}0.022 \\
(0.51)\end{array}$ & $\begin{array}{c}0.101 \\
(0.09)\end{array}$ & $\begin{array}{c}-0.027 \\
(0.05)\end{array}$ & $\begin{array}{c}0.030 \\
(0.05)\end{array}$ & $\begin{array}{r}-0.013 \\
(0.01)\end{array}$ & $\begin{array}{c}0.006 \\
(0.01)\end{array}$ \\
\hline$D E X P$ & $\begin{array}{l}0.841^{*} \\
(0.12)\end{array}$ & $\begin{array}{l}0.410^{*} \\
(0.10)\end{array}$ & $\begin{array}{l}0.585^{*} \\
(0.13)\end{array}$ & $\begin{array}{l}0.292^{*} \\
(0.12)\end{array}$ & $\begin{array}{c}-0.173^{*} \\
(0.06)\end{array}$ & $\begin{array}{c}-0.068 \\
(0.05)\end{array}$ \\
\hline$K S A$ & $\begin{array}{c}-0.012 * \\
(0.004)\end{array}$ & $\begin{array}{c}-0.007^{*} \\
(0.003)\end{array}$ & $\begin{array}{c}-0.009^{*} \\
(0.005)\end{array}$ & $\begin{array}{c}-0.005 * * \\
(0.003)\end{array}$ & $\begin{array}{c}-0.022^{*} \\
(0.003)\end{array}$ & $\begin{array}{c}0.001 \\
(0.002)\end{array}$ \\
\hline CAPEXT & $\begin{array}{r}0.024 \\
(0.12)\end{array}$ & $\begin{array}{c}0.101 \\
(0.09)\end{array}$ & $\begin{array}{c}-0.032 \\
(0.14)\end{array}$ & $\begin{array}{c}0.102 \\
(0.14)\end{array}$ & $\begin{array}{c}-0.338^{*} \\
(0.10)\end{array}$ & $\begin{array}{l}0.145^{* * 1} \\
(0.07)\end{array}$ \\
\hline $\begin{array}{c}A V G M B E / \\
100\end{array}$ & $\begin{array}{c}0.094 \\
(0.09)\end{array}$ & $\begin{array}{l}0.157^{* *} \\
(0.08)\end{array}$ & $\begin{array}{c}0.083 \\
(0.06)\end{array}$ & $\begin{array}{l}0.157^{*} \\
(0.06)\end{array}$ & $\begin{array}{l}0.093^{*} \\
(0.02)\end{array}$ & $\begin{array}{l}0.083^{*} \\
(0.01)\end{array}$ \\
\hline $\ln E M P$ & $\begin{array}{c}-0.211 \\
(0.18)\end{array}$ & $\begin{array}{l}0.286^{* * *} \\
(0.17)\end{array}$ & $\begin{array}{c}-0.015 \\
(0.22)\end{array}$ & $\begin{array}{l}0.334 * * * \\
(0.21)\end{array}$ & $\begin{array}{c}-0.472 * \\
(0.21)\end{array}$ & $\begin{array}{c}-0.554^{*} \\
(0.16)\end{array}$ \\
\hline $\ln E M P 2$ & $\begin{array}{c}0.036^{*} \\
(0.017)\end{array}$ & $\begin{array}{c}0.000 \\
(0.02)\end{array}$ & $\begin{array}{r}0.023 \\
(0.02)\end{array}$ & $\begin{array}{c}-0.003 \\
(0.02)\end{array}$ & $\begin{array}{c}0.088^{*} \\
(0.02)\end{array}$ & $\begin{array}{l}0.069 * \\
(0.02)\end{array}$ \\
\hline RECES & $\begin{array}{c}-0.248^{*} \\
(0.10)\end{array}$ & $\begin{array}{c}-0.184 * * \\
(0.10)\end{array}$ & $\begin{array}{c}-0.089 \\
(0.09)\end{array}$ & $\begin{array}{c}-0.158^{* *} \\
(0.09)\end{array}$ & $\begin{array}{r}0.017 \\
(0.03)\end{array}$ & $\begin{array}{c}-0.169^{*} \\
(0.03)\end{array}$ \\
\hline$E P$ & $\begin{array}{l}0.552^{*} \\
(0.11)\end{array}$ & $\begin{array}{c}-0.265^{*} \\
(0.10)\end{array}$ & $\begin{array}{l}0.558^{*} \\
(0.14)\end{array}$ & $\begin{array}{c}-0.256^{*} \\
(0.13)\end{array}$ & - & - \\
\hline CISP & $\begin{array}{c}-0.326 \\
(0.21)\end{array}$ & $\begin{array}{c}-0.216 \\
(0.21)\end{array}$ & $\begin{array}{c}-0.199 \\
(0.20)\end{array}$ & $\begin{array}{c}-0.242 \\
(0.22)\end{array}$ & $\begin{array}{c}-0.359^{*} \\
(0.09)\end{array}$ & $\begin{array}{c}-0.479 * \\
(0.07)\end{array}$ \\
\hline$x^{2}$ & $\begin{array}{l}333.0 \\
(17)\end{array}$ & $\begin{array}{l}322.1 \\
(17)\end{array}$ & $\begin{array}{l}136.7 \\
(17)\end{array}$ & $\begin{array}{l}163.0 \\
(17)\end{array}$ & $\begin{array}{l}898.2 \\
(13)\end{array}$ & $\begin{array}{l}264.8 \\
(13)\end{array}$ \\
\hline LR & $\begin{array}{l}136.7 \\
(1)\end{array}$ & $\begin{array}{l}159.9 \\
(1)\end{array}$ & $\begin{array}{l}238.7 \\
(142)\end{array}$ & $\begin{array}{l}209.1 \\
(142)\end{array}$ & $\begin{array}{l}375.38 \\
(143)\end{array}$ & $\begin{array}{l}368.24 \\
(143)\end{array}$ \\
\hline
\end{tabular}

Notes: Sample size: 2769 observations; Time and industry dummies included; Standarc errors are in parenthesis; * Significant at 1 per cent; ** at 5 per cent; *** at 10 per cent: Pooled levels present estimates of Equation (6). Random effects correspond to estimates of Equation (7). Linear effects present estimates of Equation (8). $\chi^{2}$ : Chi-squared test of join significance of the estimates (degrees of freedom): LR: Likelihood ratio test of random effects versus pooled levels (cols one and two), linear effects versus random effects (cols three anc four) and linear effects versus pooled levels (cols five and six) (degrees of freedom).

However, since firm effects are potentially correlated with the regressors, as explained above, the random effects specification could provide inconsistent parameter estimates. The columns under the heading 'linear effects' report parameter estimates of Equation (8), allowing for correlation among effects and variables. These results show that managerial ability or other unobserved time-invariant characteristics of the firm are important determinants of the innovation frequencies. For example, firms with foreign
Table 7.3 Dynamic models

\begin{tabular}{|c|c|c|c|c|c|c|}
\hline & \multicolumn{2}{|c|}{ Pooled levels } & \multicolumn{2}{|c|}{ Random effects } & \multicolumn{2}{|c|}{ Linear effects } \\
\hline & IPROD & IPROC & IPROD & IPROC & IPROD & $I P R O C$ \\
\hline Intercept & $\begin{array}{c}-3.529 * \\
(1.39)\end{array}$ & $\begin{array}{c}-3.514 * \\
(1.27)\end{array}$ & $\begin{array}{c}-1.177^{* *} \\
(0.66)\end{array}$ & $\begin{array}{c}-4.034^{*} \\
(1.10)\end{array}$ & & \\
\hline$I P R O D_{t-1}$ & $\begin{array}{l}2.020^{*} \\
(0.11)\end{array}$ & & $\begin{array}{l}1.292^{*} \\
(0.10)\end{array}$ & - & $\begin{array}{l}0.845^{*} \\
(0.04)\end{array}$ & - \\
\hline$I P R O C_{t-1}$ & & $\begin{array}{l}1.774^{*} \\
(0.10)\end{array}$ & - & $\begin{array}{l}0.824^{*} \\
(0.09)\end{array}$ & - & $\begin{array}{l}0.259^{*} \\
(0.03)\end{array}$ \\
\hline GINST/IO & $\begin{array}{l}0.444^{*} \\
(0.15)\end{array}$ & $\begin{array}{c}0.488^{*} \\
(0.15)\end{array}$ & $\begin{array}{c}0.468^{*} \\
(0.15)\end{array}$ & $\begin{array}{l}0.565^{*} \\
(0.16)\end{array}$ & $\begin{array}{c}-0.127^{* *} \\
(0.07)\end{array}$ & $\begin{array}{c}-0.001 \\
(0.05)\end{array}$ \\
\hline$S P I L L$ & $\begin{array}{c}-0.018 \\
(0.05)\end{array}$ & $\begin{array}{c}0.094 \\
(0.11)\end{array}$ & $\begin{array}{c}-0.028 \\
(0.05)\end{array}$ & $\begin{array}{r}0.047 \\
(0.06)\end{array}$ & $\begin{array}{c}-0.048^{*} \\
(0.01)\end{array}$ & $\begin{array}{c}0.008 \\
(0.01)\end{array}$ \\
\hline$D E X P$ & $\begin{array}{l}0.599 * \\
(0.12)\end{array}$ & $\begin{array}{l}0.314^{*} \\
(0.11)\end{array}$ & $\begin{array}{l}0.614^{*} \\
(0.13)\end{array}$ & $\begin{array}{l}0.298^{*} \\
(0.12)\end{array}$ & $\begin{array}{c}-0.068 \\
(0.05)\end{array}$ & $\begin{array}{c}-0.030 \\
(0.04)\end{array}$ \\
\hline$K S A$ & $\begin{array}{c}-0.009^{* *} \\
(0.005)\end{array}$ & $\begin{array}{c}-0.006^{*} \\
(0.003)\end{array}$ & $\begin{array}{c}-0.009^{* *} \\
(0.005)\end{array}$ & $\begin{array}{c}-0.006^{* * * *} \\
(0.004)\end{array}$ & $\begin{array}{c}0.018^{*} \\
(0.002)\end{array}$ & $\begin{array}{c}-0.001 \\
(0.002)\end{array}$ \\
\hline CAPEXT & $\begin{array}{c}0.029 \\
(0.13)\end{array}$ & $\begin{array}{r}0.091 \\
(0.12)\end{array}$ & $\begin{array}{r}-0.001 \\
(0.14)\end{array}$ & $\begin{array}{c}0.101 \\
(0.13)\end{array}$ & $\begin{array}{c}-0.347^{*} \\
(0.08)\end{array}$ & $\begin{array}{c}0.155^{*} \\
(0.07)\end{array}$ \\
\hline $\begin{array}{l}A V G M B E / \\
100\end{array}$ & $\begin{array}{c}0.109 \\
(0.10)\end{array}$ & $\begin{array}{l}0.148^{* * * *} \\
(0.09)\end{array}$ & $\begin{array}{c}0.096 \\
(0.08)\end{array}$ & $\begin{array}{l}0.151^{*} \\
(0.07)\end{array}$ & $\begin{array}{l}0.078^{*} \\
(0.02)\end{array}$ & $\begin{array}{l}0.083^{*} \\
(0.01)\end{array}$ \\
\hline $\ln E M P$ & $\begin{array}{r}-0.019 \\
(0.19)\end{array}$ & $\begin{array}{c}0.166 \\
(0.18)\end{array}$ & $\begin{array}{r}-0.001 \\
(0.21)\end{array}$ & $\begin{array}{c}0.269 \\
(0.21)\end{array}$ & $\begin{array}{c}0.240 \\
(0.17)\end{array}$ & $\begin{array}{c}-0.561^{*} \\
(0.14)\end{array}$ \\
\hline $\ln E M P 2$ & $\begin{array}{c}0.013 \\
(0.02)\end{array}$ & $\begin{array}{c}0.003 \\
(0.02)\end{array}$ & $\begin{array}{c}0.015 \\
(0.02)\end{array}$ & $\begin{array}{r}-0.001 \\
(0.02)\end{array}$ & $\begin{array}{c}-0.006 \\
(0.02)\end{array}$ & $\begin{array}{l}0.068^{*} \\
(0.02)\end{array}$ \\
\hline RECES & $\begin{array}{c}-0.252^{*} \\
(0.12)\end{array}$ & $\begin{array}{c}-0.238^{*} \\
(0.10)\end{array}$ & $\begin{array}{l}-0.181^{* * *} \\
(0.11)\end{array}$ & $\begin{array}{c}-0.198^{*} \\
(0.10)\end{array}$ & $\begin{array}{r}-0.009 \\
(0.03)\end{array}$ & $\begin{array}{c}-0.170^{*} \\
(0.02)\end{array}$ \\
\hline$E P$ & $\begin{array}{l}0.487^{*} \\
(0.12)\end{array}$ & $\begin{array}{c}-0.207^{*} \\
(0.10)\end{array}$ & $\begin{array}{l}0.515^{*} \\
(0.13)\end{array}$ & $\begin{array}{c}-0.234^{*} \\
(0.12)\end{array}$ & - & - \\
\hline CISP & $\begin{array}{c}-0.250 \\
(0.25)\end{array}$ & $\begin{array}{c}-0.182 \\
(0.24)\end{array}$ & $\begin{array}{c}-0.248 \\
(0.24)\end{array}$ & $\begin{array}{c}-0.213 \\
(0.24)\end{array}$ & $\begin{array}{c}-0.398^{*} \\
(0.07)\end{array}$ & $\begin{array}{c}-0.330^{*} \\
(0.06)\end{array}$ \\
\hline$x_{1}^{2}$ & $\begin{array}{l}337.2 \\
(1)\end{array}$ & $\begin{array}{l}314.7 \\
(1)\end{array}$ & $\begin{array}{l}166.9 \\
(1)\end{array}$ & $\begin{array}{l}83.82 \\
(1)\end{array}$ & $\begin{array}{l}446.3 \\
(1)\end{array}$ & $\begin{array}{l}74.53 \\
\text { (1) }\end{array}$ \\
\hline$\chi_{2}^{2}$ & $\begin{array}{l}718.3 \\
(18)\end{array}$ & $\begin{array}{l}658.3 \\
(18)\end{array}$ & $\begin{array}{l}328.6 \\
(18)\end{array}$ & $\begin{array}{l}257.1 \\
(18)\end{array}$ & $\begin{array}{l}538.7 \\
(14)\end{array}$ & $\begin{array}{l}177.9 \\
(14)\end{array}$ \\
\hline$\chi_{3}^{2}$ & - & - & - & - & $\begin{array}{l}0.42 \\
(1)\end{array}$ & $\begin{array}{l}0.12 \\
(1)\end{array}$ \\
\hline LR & $\begin{array}{l}164.6 \\
(1)\end{array}$ & $\begin{array}{l}290.6 \\
(1)\end{array}$ & $\begin{array}{l}210.1 \\
(143)\end{array}$ & $\begin{array}{l}369.6 \\
(143)\end{array}$ & $\begin{array}{l}204.06 \\
(144)\end{array}$ & $\begin{array}{l}239.34 \\
(144)\end{array}$ \\
\hline
\end{tabular}

Notes: Sample size: 2769 observations; Time and industry dummies included. Standard errors are in parenthesis. ${ }^{*}$ Significant at 1 per cent; ** at 5 per cent; *** at 10 per cent Pooled levels present estimates of Equation (6). Random effects correspond to estimates of Equation (7). Linear effects present estimates of Equation (8). $\chi_{1}^{2}$ : Chi-squared test of dynamic versus static models (degrees of freedom). $\chi_{2}^{2}$ : Chi-squared test of joint significance of the estimates (degrees of freedom). $\chi_{3}^{2}$ : Chi-squared test on the significance of the alternative innovation indicator (degrees of freedom). LR: Likelihood ratio test of random effects versus pooled levels (cols one and two), linear effects versus random effects (cols three and four) and linear effects versus pooled levels (cols five and six) (degrees of freedom) 
capital innovate significantly less in product than firms with national ownership, once we control for correlated unobserved heterogeneity. The reverse is true in the case of process innovation. The LR tests indicate the rejection of the null of absence of correlation, conditional on their presence, among effects and variables at usual levels of significance.

Our second concern is to test experience. We try to capture experience using the lagged latent or lagged observed indicators. Although all columns present results with the lagged observed indicator as the explanatory variable, the coefficients in the linear effects specification do not differ from those including the predicted lagged latent variable. The effect of experience is very important, as many authors have shown in other contexts (see Hausman et al., 1984 in an application with patents). The results are affected independently of the specification considered. There are at least two reasons. The first one concerns misspecification of the static models as confirmed by the $\chi^{2}$ tests (see Table 7.3). The second has to do with the correlation among effects and variables. If we include a lagged dependent variable in a model with unobserved heterogeneity, at least this variable is correlated with the effects, and in their absence with the mixed error. Again, as both experience and managerial ability affect the innovation probabilities positively, the parameters of the static models are generally upwards-biased. This can be observed by comparing columns 1 to 3 in Table 7.2 with their counterparts in Table 7.3. There is no common pattern in the results reported in columns under the heading 'linear effects', because the scheme of correlation is more complex, given the assumption that the effects depend on all the exogenous variables. Therefore, static models representing innovation decisions are too restrictive to impose on the data. Moreover, the sign of the coefficients indicates that Spanish manufacturing firms innovating in the past have a higher probability of continuing to innovate, as expected.

The effect of experience once we control for the correlation among effects and variables can be tested by comparing the corresponding columns in Tables 7.2 and 7.3. Misspecification of the dynamic relationship has important consequences for the results. The indicator of export activities has no influence on the decision to innovate in product once we have controlled for the variable 'experience'. This contrasts with its contra-intuitive sign obtained in the static specification. Moreover, the size profile on innovation probabilities is the same in the process decision and the reverse in the product innovation decision, a result already detected by Martínez-Ros and Labeaga (1996) in a product innovation count equation using this same survey. Finally, the spillover effects and the effects of the vertical integration variable are also affected. The negative sign of the spillover effect in the product innovation decision indicates the absence of competitive advantage because of the easy imitation.

When comparing coefficients in columns 1 to 6 on Tables 7.2 and 7.3, we observe that the results depend on both the method used to estimate the equation and the static or dynamic nature of the specification. However, the testing procedure allows us to focus in the dynamic linear effects specification in Table 7.3. This model has been estimated using the withingroups procedure, as previously stated. In the reduced form equation for each year, we include all lags and leads of the exogenous conditionings plus the lagged indicators, under the assumption of uncorrelated mixed errors. On the other hand, we consider that the knowledge stock is endogenous, and consequently we adjust an auxiliary regression using again all exogenous factors.

Concerning results, we must first emphasize that the determinants of both innovation activities are very different except for the degree of market competition and the level of firm vertical integration. High concentration in the product market encourages firms to carry out product and process innovations of the same magnitude. It confers validity to the Schumpeter hypothesis in the sense that an important degree of monopoly power ex ante constitutes a good source to generate innovations. On the other hand, we observe that the higher the degree of vertical integration, the lower the probability of innovation both in product and in process, as expected.

The other conditioning variables have different effects on product and process innovations. Experience affects the probability of product innovation much more than process innovation. It could be related to the process in developing the new products. The experience in carrying out product innovation jointly with the ability of the manager, the culture of the firm or the know-how lead firms to have more competitive advantage in producing such types of innovation. Justification for absence of effects in the knowledge stock could be found in the importance of both heterogeneity and experience. We must note that firm effects (managerial ability, corporate culture, know-how, or other unobserved time-invariant variable), experience and the knowledge stock act in the same way concerning innovation probabilities. Consequently, when we take into account the dynamic structure of the model and the presence of these unobserved effects, the importance of the knowledge stock vanishes in both equations. Part of the technological effort is captured by the probability of developing new products in the past and the other part of it is captured by the firm effect. Although this seems to be an important and surprising result when comparing all the estimated specifications, we can find some reasons for it. When comparing the positive and significant effect that we find in both the pooled and the 
random effects models, the only difference from the linear effects specification is that in the latter we allow for correlation among effects and variables. The knowledge stock is a good candidate to be correlated with any of the time-invariant characteristic captured by unobserved heterogeneity. Moreover, the effect of experience is very important independently of the maintained hypothesis about the effects. However, when including them in the specification, the magnitude of the coefficients of IPROD ${ }_{t-1}$ and $I P R O C_{t-1}$ reduces. Finally, when assuming correlated effects, these coefficients reduce their magnitude again.

Another interesting result is the different influence of technological opportunity on both decisions. For product innovation, the spillover effect is negative, while for process innovation the effect is not significant. This is reasonable, since product innovation is easier to imitate than process innovation and, as a consequence, the threat of rivals is very much more active in this kind of activity.

High-capital-intensive firms tend to innovate more in product than in process. They reduce the costs of making new products using internal financing. The coefficient of this variable in the process innovation decision is not significantly different from zero. Although we expect a discipline effect of the foreign capital variable, it only happens in the process innovation decision. Managerial ability and experience seem to be more important in the development of new products, and once we take account of these variables, foreign ownership firms have a smaller probability of innovating than national ownership ones. Concerning the export variable, we do not find a discipline effect of competing in foreign markets, either in the decision of making product innovations or in the decision to conduct process innovations. It seems that integrated markets (as the Spanish one) require the same products and processes for competing.

Neither product nor process innovation require large firms with high complementary resources. In fact, only the very largest firms ( 5 per cent of the sample by size) innovate more in process than the rest. So, we find a threshold at the level of 2000 employees, in such a way that the probability of conducting process innovation reduces with size, except for those firms with more than 2000 workers.

We find that process innovation probabilities are affected by the state of demand, while product innovation decisions are not. A priori, we expected both innovation decisions to be affected negatively. However, only the influence on the process innovation frequencies can be justified, since firms developing new processes need a good environment in order to extract results. Moreover, process innovation needs more financing (either internal or external) than product innovation. The state of demand, which could be considered as a subjective proxy for the state of the economy, makes firms cut sources of financing and so reduce the innovation probability.

A final comment concerns complementarity between the two innovation decisions. We have tested this assumption by including the alternative innovation indicator in each of the equations. There are important effects of the lagged product innovation variable in the process innovation frequencies, and of the lagged process innovation indicator on the product innovation decisions when we do not control by own experience (either controlling or not for unobserved heterogeneity). However, once the lagged own variable is included, the effect of the alternative decision vanishes. The $\chi^{2}$ tests corresponding to both equations are reported in Table 7.3. These figures do not reject the null of absence of complementary relationships at usual significance levels. This confirms the descriptive figures already shown in Table 7.1.

\subsection{CONCLUDING REMARKS}

We have estimated in this chapter several alternatives of discrete choice models for panel data, with the main purpose of analyzing the determinants of innovation activity, using a Spanish survey, the Encuesta Sobre Estrategias Empresariales, for the period 1990-3. Empirical evidence indicates that in the decisions to carry out innovations, there are different determinants (or effects) in the two equations. We find that the lagged own dependent variable is important, while, after controlling for this dynamic effect, the significance of the alternative indicator vanishes. In this sense, complementarity is not a requirement for innovating in both product and process once the model is specified correctly. We can affirm that once the experience effect and the unobserved heterogeneity are controlled for, the other determinants of innovation are affected sensibly. The Schumpeter hypothesis in terms of market environment is confirmed, but it is not possible to make conclusive comments in terms of firm size, since neither for product innovation nor for process innovation is size an important factor. Only those firms with more than 2000 employees decide to develop more process innovation than the rest. Finally, unobserved heterogeneity, which captures managerial ability, corporate culture, know-how or other time invariant variables, constitute an important determinant of innovation frequencies of Spanish manufacturing firms. 
Appendix: Data

Table A7.1 Industry classification

\begin{tabular}{lll}
\hline Industries & NACE-CLIO & CNAE-74I \\
\hline $\begin{array}{l}\text { 1. Chemical and metal } \\
\text { products (CHEM) }\end{array}$ & $1,2,3,4$ & $22,24,25,31$ \\
$\begin{array}{l}\text { 2. Electric materials (ELEC) } \\
\text { 3. Machinery, motors and }\end{array}$ & 6,7 & $33,39,34,35$ \\
$\quad$ vehicles (MACHIN) & $5,8,9$ & $32,36,37,38$ \\
$\begin{array}{l}\text { 4. Food and beverages (FOOD) } \\
\text { 5. Leather, wooden and }\end{array}$ & $10,11,12$ & 41,42 \\
$\quad$ paper (LEATHER) & $13,14,15,16,17,18$ & $43,44,45,46,47,48,49$ \\
\hline
\end{tabular}

Explanation: 1 "CNAE" is the Spanish National Classification of Economic Activities (1974).

Table A7.2 Descriptive statistics

\begin{tabular}{|c|c|c|c|c|c|c|}
\hline & \multicolumn{2}{|c|}{ All Firms } & \multicolumn{2}{|c|}{ Product Innovation } & \multicolumn{2}{|c|}{ Process Innovation } \\
\hline & Mean & Std. dev. & Mean & Std. dev. & Mean & Std. dev. \\
\hline$G$ & 0.016 & 0.037 & 0.027 & 0.051 & 0.023 & 0.043 \\
\hline SPILL & 0.019 & 0.693 & 0.044 & 0.871 & 0.047 & 0.829 \\
\hline$D E X P$ & 0.543 & 0.498 & 0.769 & 0.422 & 0.721 & 0.448 \\
\hline KSA & 6.355 & 28.01 & 2.131 & 7.971 & 2.534 & 10.53 \\
\hline CAPEXT & 0.218 & 0.413 & 0.324 & 0.468 & 0.318 & 0.466 \\
\hline$A V G M B E$ & 0.106 & 0.027 & 0.102 & 0.023 & 0.102 & 0.027 \\
\hline $\ln E M P$ & 4.320 & 1.595 & 4.986 & 1.668 & 5.031 & 1.605 \\
\hline RECES & 0.350 & 0.477 & 0.357 & 0.479 & 0.354 & 0.478 \\
\hline CISP & 0.595 & 0.212 & 0.586 & 0.263 & 0.587 & 0.251 \\
\hline$E P$ & 0.661 & 0.473 & 0.714 & 0.452 & 0.632 & 0.482 \\
\hline CHEM & 0.268 & 0.443 & 0.247 & 0.432 & 0.278 & 0.448 \\
\hline FOOD & 0.169 & 0.375 & 0.154 & 0.361 & 0.157 & 0.364 \\
\hline ELEC & 0.095 & 0.294 & 0.149 & 0.356 & 0.111 & 0.315 \\
\hline MACHIN & 0.121 & 0.326 & 0.157 & 0.364 & 0.162 & 0.368 \\
\hline LEATHER & 0.347 & 0.476 & 0.293 & 0.455 & 0.292 & 0.455 \\
\hline No. of observations & \multicolumn{2}{|c|}{$3692(100 \%)$} & \multicolumn{2}{|c|}{$942(25.5 \%)$} & \multicolumn{2}{|c|}{$1149(31,1 \%)$} \\
\hline
\end{tabular}

Notes: Sample in each innovation type corresponds to the observations in the period $1990-4$. The percentage over the total number of observations is in brackets.

Definition of variables: G: Knowledge stock obtained using Equation (2). SPILL: Industry knowledge stock using Equation (2) removing own-firm R\&D expenditure. DEXP: Dummy variable equals one if firm exports in any period. KSA: Ratio of fixed assets to sales. CAPEXT: Dummy variable equals one if firm has foreign capital as ownership. AVGMBE: Average gross profit margin of the industry. LnEMP: Log of total firm employment. CISP: Share of intermediate products over total firm production. RECES: Dummy variable equals one when firm considers a recession in its production market. EP: Dummy variable takes one when firm produces a standard product. CHEM, FOOD, ELEC, MACHIN and LEATHER: Industry dummies.

\section{Notes}

* This chapter is based on the paper presented at the workshop of the TSER Network on Innovation and Economic Change held in Delft in February 1999. We are grateful to participants and a referee for many useful comments. We are also grateful to the Ministry of Industry and Energy for providing the data used in the study. The authors acknowledge financial support from DGES projects PB97-0185 and PB95-0980, respectively. The usual disclaimer applies.

1. CNAE is the National Classification of Economic Activities.

2. We use the balanced panel instead of the unbalanced one both for simplicity and for the need to use the maximum number of periods, given the dynamic nature of our model. However, all the features of the models presented below are applicable to both types of data.

3. Although we have available the number of product innovations, we have not used it in this chapter, since we are interested in analyzing the determinants of the decisions to develop innovation activities. However, Martínez and Labeaga (1996) present some evidence using the count of product innovations.

4. See Griliches and Mairesse (1984), or Hall (1990).

5. Note that we could express these equations in terms of an unobserved variable, profits produced by innovation, and then link the decision with profits, assuming that we observe a firm innovating when the profits of doing this activity are larger than those corresponding to the alternative regime.

6. In order to estimate the parameters of interest consistently, several solutions have been proposed as the conditional logit, or logit with fixed effects (Andersen, 1973; and Chamberlain, 1980). Although this procedure does not place restrictions on the conditional distribution of the effects given the regressors, it requires strict exogeneity of all the regressors, thus ruling out possible dynamic specifications.

7. There are different alternatives for estimating random effects models, as Keane's (1994) method of simulated moments, which allows the estimation of models with complex patterns of serial correlation without the need to evaluate multivariate integrals. Honore and Kyriazidou (1996) propose the estimation of models in the presence of lagged endogenous regressors, and unobserved effects in the spirit of the conditional logit (that is, without modelling the effects explicitly). However, this method rules out non-stationary variables, time-series heteroscedasticity or serially-correlated mixed errors. Finally, Arellano and Carrasco (1997) present a model which takes account of heterogeneity without restricting the form of the effects, and allows for the inclusion of predetermined variables. They propose to estimate the model either by minimum distance, maximum likelihood, or by using a generalized method of moments.

\section{References}

AMEMIYA, T. (1986) Advanced Econometrics. Oxford: Basil Blackwell.

ANDERSEN, E. B. (1973) Conditional Inference and Model Measuring.

Copenhagen: Mentalhygiejnisk Forlag. 
ARELLANO, M. and CARRASCO, R. (1997) 'Discrete Choice Panel Data Models with Predetermined Variables', DT 9716. Madrid: CEMFI.

ARROW, K. (1962) 'Economic Welfare and the Allocation of Resources for Inventions', in R. R. Nelson (ed.), The Rate and Direction of Inventive Activity. Princeton, NJ: Princeton University Press.

BALDWIN, J., HANEL, P. and SABOURIN, D. (1999) 'Determinants of Innovation Activity in Canadian Manufacturing Firms: The Role of Intellectual Property Rights', Paper presented at the TSER Network on Innovation and Economic Change, Delft.

BLUNDELL, R. W., BOND, S., DEVEREUX, M. and SCHIANTARELLI, F. (1992) 'Investment and Tobin's Q', Journal of Econometrics, vol. 51, pp. 233-57.

BLUNDELL, R. W., GRIFFITH, R. and VAN REENEN, J. (1995) 'Dynamic Count Data Models of Technological Innovation', The Economic Journal, vol. 105 , pp. $333-44$.

BOUND, J., CUMMINS, C., GRILICHES, Z., HALL, B. H. and JAFFE, A. (1984) 'Who Does R\&D and Who Patents?', in Z. Griliches (ed.), R\&D, Patents and Productivity. Chicago: University of Chicago Press and NBER.

BOVER, O. and ARELLANO, M. (1997) 'Estimating Dynamic Limited Dependent Variable Models from Panel Data', Investigaciones Económicas vol. 21, pp. 141-65.

CHAMBERLAIN, G. (1980) 'Analysis of Covariance with Qualitative Data', Review of Economic Studies, vol. 47, pp. 225-38.

CHAMBERLAIN, G. (1984) 'Panel Data', in Z. Griliches and M. Intriligator (eds), Handbook of Econometrics, vol. II, Amsterdam: North-Holland, pp. 1247-318.

COX, D. R. (1970) Analysis of Binary Data, London: Methuen.

CRÉPON, B. and DUGUET, E. (1997) 'Research and Development, Competition and Innovation. Pseudo-maximum Likelihood and Simulated Maximum Likelihood Methods Applied to Count Data Models with Heterogeneity', Journal of Econometrics, vol. 79, pp. 355-78.

GARCÍA-MONTALVO, J. (1993) 'Patents and R\&D at the Firm Level: A New Look', Revista Española de Economía, Monográfico: Investigación y Desarrollo, pp. 67-82.

GRILICHES, Z. (1990) 'R\&D, Patent Statistics as Economic Indicators: A Survey', Journal of Economic Literature, vol. 28, pp. 1661-707.

GRILICHES, Z. and MAIRESSE, J. (1984) 'Productivity and R\&D at the Firm Level', in Z. Griliches (ed.), R\&D, Patents and Productivity, University of Chicago Press, pp. 339-74.

HALL, B. H. (1990) 'The Impact of Corporate Restructuring on Industrial Research and Development', Brooking Papers on Economic Activity: Microeconomics, pp. 85-124.

HALL, B. H. and MAIRESSE, J. (1993) Exploring the Productivity of Research and Development in French Manufacturing Firms. National Bureau of Economic Research and Centre de Reserche en Economie et Statistique, WP 9326.

HALL, B. H., GRILICHES, Z. and HAUSMAN, J. (1986) 'Patents and R\&D: Is There a Lag?', International Economic Review', vol. 27, pp. 265-83.

HAUSMAN, J., HALL, B. and GRILICHES, Z. (1984) 'Econometric Models for Count Data and an Application to the Patents-R\&D Relationship', Econometrica, vol. 52, pp. 909-38.
HECKMAN, J. J. (1981) 'Statistical Models for Discrete Panel Data', in C. F. Manski and D. McFadden (eds), Structural Analysis of Discrete Data with Econometric Applications, Cambridge, Mass.: MIT Press.

HONORE, B. and KYRIAZIDOU, E. (1996) 'Panel Data Discrete Choice Models with Lagged Dependent Variables', Mimeo (Princeton University).

KEANE, M. (1994) 'A Computationally Practical Simulation Estimator for Panel Data', Econometrica, vol. 62, pp. 95-116.

KLEINKNECHT, A. (1989) 'Firm Size and Innovation. Observations in Dutch Manufacturing Industries', Small Business Economics, vol. 1, pp. 215-22.

LEVIN, R. C. and REISS, P. C. (1989) 'Cost-reducing and Demand-creating R\&D with Spillovers', Rand Journal of Economics, vol. 19, pp. 538-56.

LUNN, J. (1986) 'An Empirical Analysis of Process and Product Patenting: A Simultaneous Equation Framework', Journal of Industrial Economics, vol. 34, pp. 319-30.

MARTÍNEZ-ROS, E. and LABEAGA, J. M. (1996) 'The Relationship between Firm Size and Innovation Activity: A Double Decision Approach', WP 96/04, Universitat Autònoma de Barcelona.

MARTÍNEZ-ROS, E. (1998) 'Explaining the Decisions to Carry Out Product and Process Innovations: The Spanish Case', WP 98/98, Universidad Carlos III de Madrid.

PAVITT, K., ROBSON, M. and TOWNSEND, J. (1987) 'The Size Distribution of Innovating Firms in the UK: 1945-1983', Journal of Industrial Economics, vol. 35 , pp. 297-316.

SEGURA, J. (ed.) (1993) Las Empresas Industriales en 1991, Madrid: MINER.

SCHUMPETER, J. A. (1942) Capitalism, Socialism and Democracy, New York: Harper. 